\title{
Involvement of gonadal steroid hormone disturbance in altered prolactin receptor gene expression in the liver of diabetic mice
}

\author{
T Yasui, T Murakami, T Maeda and T Oka \\ Laboratory of Genetics and Physiology, National Institutes of Diabetes, Digestive and Kidney Diseases, National Institutes of Health, Bethesda, Maryland, \\ 20892, USA \\ (Requests for offprints should be addressed to T Oka, Laboratory of Genetics and Physiology, National Institutes of Diabetes, Digestive and Kidney Diseases, \\ National Institutes of Health, Building 8, Room 106, 9000 Rockville Pike, Bethesda, Maryland, 20892, USA)
}

\begin{abstract}
The levels of mRNA for long and three short forms of prolactin receptor (PRLR) were examined in the livers of normal $(\mathrm{db}+/ \mathrm{db}-)$ and insulin-resistant diabetic $(\mathrm{db}+/$ $\mathrm{db}+$ ) mice to assess the role of gonadal steroid hormones in the regulation of PRLR gene expression in diabetes mellitus. In females, plasma levels of testosterone in diabetic mice were higher, and those of $17 \beta$-estradiol were lower when compared with levels in normal mice. By contrast, diabetic male mice had lower plasma levels of testosterone than normal males and showed no significant difference in the low circulating level of $17 \beta$-estradiol compared with normal males. The short 3 form of PRLR (PRLR3) mRNA was the most abundant in the liver of both normal and diabetic mice. In addition, the level of PRLR 3 mRNA in normal females was 8-fold higher than in normal males. The level of PRLR 3 mRNA in diabetic females was approximately a quarter lower than in normal
\end{abstract}

females, whereas the level of PRLR 3 mRNA in diabetic males was approximately 2 -fold higher than in normal males. During postnatal development, the level of PRLR3 mRNA increased during puberty in normal females, while the level in diabetic females decreased to a nadir at 7 weeks of age followed by a progressive rise. On the other hand, the levels of PRLR 3 mRNA in both normal and diabetic males decreased gradually during 5 to 14 weeks of age. Testosterone treatment of diabetic males and females resulted in a $49 \cdot 1$ and $49 \cdot 8 \%$ decrease of PRLR3 mRNA respectively. 17ß-Estradiol treatment slightly (18\%) increased levels of PRLR3 mRNA in diabetic males. These results suggest that the hepatic level of PRLR mRNA is regulated by the inhibitory effect of testosterone and the stimulatory effect of estrogen in both normal and diabetic mice.

Journal of Endocrinology (1999) 161, 33-40

\section{Introduction}

Prolactin receptor (PRLR) is a member of the cytokine receptor superfamily localized in the cell membrane, and mediates the effect of PRL on its target tissues. PRLR has been cloned from various species (Boutin et al. 1988, 1989, Davis \& Linzer 1989, Shirota et al. 1990, Moore \& Oka 1993) and shown to exist in at least two isoforms, short and long, depending upon the length of the cytoplasmic domain. The long form of PRLR has been shown to mediate the PRL stimulation of milk-protein gene expression in the mammary gland through a Janus kinase/signal transducer and activator of transcription pathway (Rui et al. 1992). However, the physiological role of short forms still remains unclear.

Although PRLR is widely distributed in mammalian tissues, the short form of receptor mRNA is most abundant in the liver (Davis \& Linzer 1989). The pituitary has an important role in regulating hepatic PRLR (Posner et al. 1974) since pituitary hormones, including growth hormone (Norstedt et al. 1981) and PRL (Manni et al.
1978), were thought to induce PRLR in the liver. On the other hand, earlier studies showed that hepatic PRLR is also influenced by gonadal steroid hormones. In female rats, ovariectomy leads to a decrease in the number of PRL binding sites in the liver, which is reversed by estrogen treatment (Kelly et al. 1975). In male rats, castration results in an increase in the number of liver PRL binding sites, while testosterone administration leads to a decrease (Aragona et al. 1976, Kelly et al. 1977). The levels of PRL binding sites vary during puberty (Maes et al. 1983), pregnancy and lactation (Jahn et al. 1991, Buck et al. 1992). More recently, it has been shown that the hepatic expression of PRLR gene is stimulated by estrogen (Jolicoeur et al. 1989) and inhibited by testosterone (Sakaguchi et al. 1994).

Possible alterations in hepatic PRLR gene expression in endocrinological disorders have not been examined extensively. Among such diseases, diabetes mellitus may be of interest because it is accompanied by disturbances in gonadal steroid hormones. Diabetic women have an increased incidence of menstrual irregularities and 
hypogonadotropic hypogonadism, whereas impotence, loss of seminal emission and impaired spermatogenesis are well recognized in men with diabetes mellitus. In these patients, disturbances in the production and secretion of gonadal steroid hormones have been observed (Djursing et al. 1982, Semple et al. 1988). In addition, streptozotocin (STZ)-induced diabetic rats were shown to have gonadal steroid hormone disorders, such as low levels of testosterone in males and high levels of testosterone in females, which were accompanied by changes in PRL binding sites in the liver (Baxter et al. 1981, Bryson \& Baxter 1986). In the present study, we examined the importance of gonadal steroid hormone disorders in the regulation of hepatic PRLR gene expression in insulin-resistant diabetic mice $(\mathrm{db}+/ \mathrm{db}+)$ by examining the levels of PRLR mRNA using the quantitative reverse transcriptase polymerase chain reaction (RT-PCR).

\section{Materials and Methods}

\section{Animals}

Diabetic mice of C57BL/Ks inbred strain $(\mathrm{db}+/ \mathrm{db}+)$ and age-matched control mice $(\mathrm{db}+/ \mathrm{db}-)$ were purchased from Jackson Laboratory, Bow Harbor, ME, USA. The symptoms of diabetic mice $(\mathrm{db}+/ \mathrm{db}+)$, caused by loss of leptin receptor, include hyperglycemia, polyuria, glycosuria, hypogonadism, extreme obesity and progressive insulin resistance. All animal care and study protocols were in compliance with the US National Institutes of Health guidelines. Treatment with $17 \beta$-estradiol and testosterone was started at 7 weeks of age and continued for 8 days. 17 $\beta$-Estradiol (Sigma Chemical Co., St Louis, MO, USA) was injected daily s.c. at a dose of $10 \mu \mathrm{g}$ in corn oil and testosterone propionate (ICN Biochemicals, Costa Mesa, CA, USA) was injected daily s.c. at a dose of $100 \mu \mathrm{g}$ in corn oil. The mice were killed by exsanguination under isoflurane anesthesia (Anaquest, Madison, WI, USA) from 1000 to $1300 \mathrm{~h}$. Blood was collected by vena cava puncture using a heparinized syringe and centrifuged at $8700 \mathrm{~g}$ for $15 \mathrm{~min}$ to obtain plasma for the assay of $17 \beta$-estradiol and testosterone; the plasma was kept at $-80{ }^{\circ} \mathrm{C}$ until assay. Liver tissues were quickly removed and frozen immediately on dry ice. The samples were kept at $-80{ }^{\circ} \mathrm{C}$ until use.

\section{$R N A$ preparation}

Liver tissues were homogenized and total cellular RNA was extracted by the guanidinium thiocyanate/cesium chloride method (Sambrook et al. 1989). The amount of total RNA was quantitated by spectrophotometry (Beckman, DU-64, Fullerton, CA, USA) at $260 \mathrm{~nm}$. Aliquots were randomly chosen and loaded on a $1.5 \%$ agarose gel to examine the relative intensity of bands of
$28 \mathrm{~S}$ and $18 \mathrm{~S}$ rRNAs. Similar intensities were observed in all samples (data not shown).

\section{Plasmid construction for synthetic internal control DNA (cDNA)}

Primers and synthetic internal control DNA used for quantitative RT-PCR are shown in Fig. 1. The plasmid pRM252 contains a $2.0 \mathrm{~kb}$ cDNA fragment encoding mouse mammary PRLR long form ligated into pSKII(+) vector, and the plasmid pRM301 contains a $1.1 \mathrm{~kb}$ cDNA fragment encoding mouse mammary PRLR short 1 form ligated into pSKII(+) vector. The plasmid pRM299 was constructed by cutting the plasmid pRM252 at the NheI and HindIII sites and ligating with a $12 \mathrm{bp}$ linker. The plasmid pRM304 was constructed by digestion of the plasmid pRM301 with NdeI and NcoI and ligated with a 12 bp linker. The plasmid pRM304 was further digested with PstI and inserted into the binding site for the primer P5 and P6, which corresponds to cytoplasmic regions specific to PRLR short 2 form and 3 form respectively. The plasmid pRM299 was amplified by PCR using the $5^{\prime}$ primer, nP3-P1, which corresponds to a cDNA sequence for PRLR short form and long form respectively, and the $3^{\prime}$ primer, P4-nP66, which corresponds to a cDNA sequence for PRLR short 1 form and long form respectively, and the product was subcloned into the vector of pCRII using an original TA cloning kit (Invitrogen, San Diego, CA, USA). This plasmid was digested with ACCI and EcoRI, and the resulting fragment was inserted into the plasmid pRM304, which was pre-digested with ACCI and EcoRI to prepare internal control DNA. The primers used for these procedures were as follows:

P1: 5'- TAC AAC ATG GCC TTT

ACC ACC TGG C -3' (1237-1297)

nP66: 5'- AGA TTG GTT CTG TTC

AAG CGA TGG T -3' (1756-1780)

nP3: 5'- GTG ACT TAC ATT GTT

GAA CCA GAG C -3' (572-596)

P4: 5'- TTC ACC AGG GAA GTC

AAC TGG AGA A -3' (914-938)

P5: 5'- ACA TGG CAG AAA CCT

TTC TGA GGA C -3' (1117-1141)

P6: 5'- GTA GTC AAG TTC CCC

TTC ATT GTC C -3' (1131-1155)

\section{Internal control RNA (cRNA) preparation}

The plasmid for the generation of cRNA was linearized by digestion with SstII. cRNA was synthesized using this linearized plasmid as a template and T7 RNA polymerase. One microgram proteinase K-treated DNA template was incubated at $37^{\circ} \mathrm{C}$ for $30 \mathrm{~min}$ under the following conditions: $5 \times$ transcription buffer, $10 \mathrm{mM}$ ribo(r)ATP, $10 \mathrm{mM}$ rGTP, $10 \mathrm{mM}$ rCTP, $10 \mathrm{mM}$ rUTP, $0.75 \mathrm{M}$ dithiothreitol and $10 \mathrm{U}$ T7 RNA polymerase (Stratagene, 

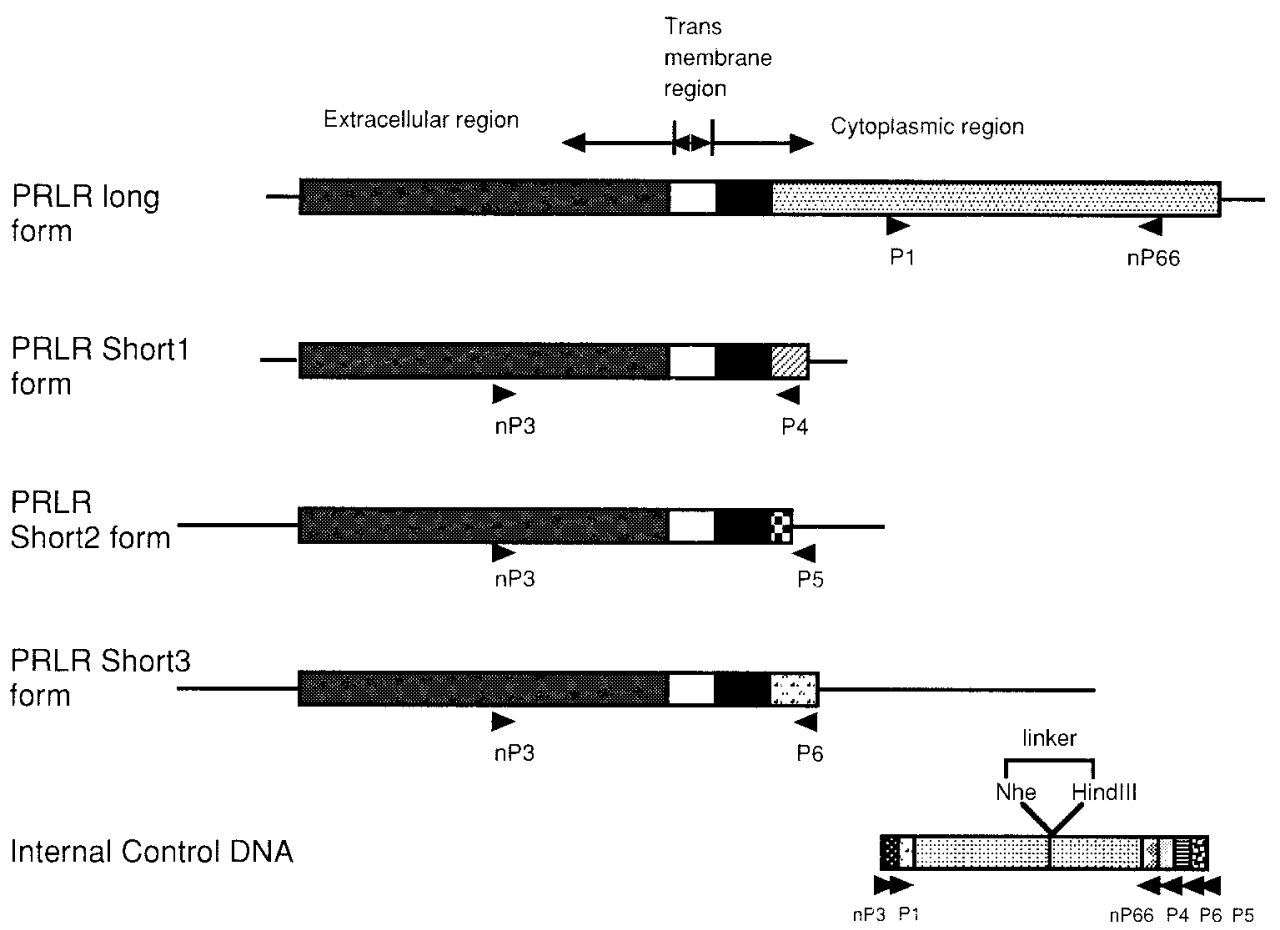

Figure 1 Schematic representation of mouse PRLR long form and three short forms of cDNAs, and synthetic internal control DNA. The dotted, white and solid regions represent the extracellular domain, the transmembrane domain and the conserved region of the cytoplasmic domain respectively. The other regions are non-conserved cytoplasmic domains. The location of the oligonucleotide primers used in quantitative RT-PCR are also shown. The oligonucleotide primers used (P1, nP66, nP3, P4, P5 and P6) are described in Materials and Methods.

La Jolla, CA, USA) in a total reaction volume of $25 \mu$. After completion of the transcription reaction, the reaction mixture was treated with $10 \mathrm{U}$ RNase-free DNaseI (Stratagene) and incubated at $37^{\circ} \mathrm{C}$ for $15 \mathrm{~min}$, followed by the phenol-chloroform extraction. After ethanol precipitation with ammonium acetate, cRNA was resuspended in diethyl pyrocarbonate-treated water. Upon electrophoresis, a single band of cRNA with an expected size was observed on a $1.5 \%$ agarose gel. The cRNA solution was diluted to $1 \times 10^{6}$ molecules/ $\mu$ in diethyl pyrocarbonate-treated water with $1 \mathrm{U} / \mu \mathrm{l}$ RNase inhibitor (Stratagene) and stored at $-80{ }^{\circ} \mathrm{C}$.

\section{Quantitative RT-PCR}

The levels of PRLR mRNA were measured by a quantitative PCR using an internal control RNA which contained multiple sites for primers corresponding to mRNAs for various forms of PRLR. This method allowed us to determine the number of PRLR mRNA molecules in total RNA samples. Primers used in this procedure were the same as those used in construction of plasmid for synthetic internal control RNA (Fig. 1). This method of quantitative PCR was based on a published modified procedure (Wang et al. 1989, Nagano \& Kelly 1994).
RT-PCR was carried out according to the manual provided by the supplier (Perkin-Elmer-Cetus, Norwalk, CT, USA). A titration assay was first performed to estimate the amount of RNA molecules. The mixture of $10 \mathrm{ng}$ total RNA and various dilutions of cRNA were reverse-transcribed in $20 \mu \mathrm{l}$ reaction volume. Reverse transcription was performed for $15 \mathrm{~min}$ at $42{ }^{\circ} \mathrm{C}$ in a reaction buffer containing $2.5 \mu \mathrm{M}$ random hexamers, $1 \mathrm{mM}$ dNTP, $1 \mathrm{U}$ RNase inhibitor and $2.5 \mathrm{U}$ murine leukemia virus reverse transcriptase. The $\mathrm{RT}$ reaction was terminated by heating at $99^{\circ} \mathrm{C}$ for $5 \mathrm{~min}$ and the samples quick-chilled on ice. The amplification conditions were as follows: $2 \mathrm{mM} \mathrm{MgCl}_{2}$ solution, $1 \times$ PCR buffer containing $1.0 \times 10^{6}$ c.p.m. of $5^{\prime}$ end labeled primer, $100 \mathrm{ng} 5^{\prime}$ non-labeled primer (P1 or nP3), $100 \mathrm{ng} 3^{\prime}$ non-labeled primer (nP66 or $\mathrm{P} 4, \mathrm{P} 5, \mathrm{P} 6)$ and $2.5 \mathrm{U}$ Taq polymerase. The amplification reaction included the following sequential steps: denaturation at $95^{\circ} \mathrm{C}$ for $2 \mathrm{~min}$ and at $94{ }^{\circ} \mathrm{C}$ for $1 \mathrm{~min}$, annealing at $60{ }^{\circ} \mathrm{C}$ for $1 \mathrm{~min}$ and extension at $72{ }^{\circ} \mathrm{C}$ for $2 \mathrm{~min}$. Thirty cycles of amplification were completed with an additional extension step at $72{ }^{\circ} \mathrm{C}$ for $7 \mathrm{~min}$. Based on the results of the initial titration assay, appropriate amounts of cRNA and total RNA were mixed and reverse transcribed in a total reaction volume of $20 \mu \mathrm{l}$ at $42{ }^{\circ} \mathrm{C}$ for 15 min under the same conditions as the initial titration 
assay. After the reverse transcription reaction, 3-fold serial dilutions of RT reaction mixture were prepared. Ten microliters of each dilution of $\mathrm{RT}$ reaction were amplified under the same conditions as the initial titration assay. The resulting PCR products were electrophoresed in a $5 \%$ polyacrylamide gel in Tris-borate/EDTA electrophoresis buffer. The gels were dried and exposed for autoradiography. Specific bands corresponding to the various forms of PRLR were cut out from the dried gel and the radioactivity was determined by a liquid scintillation spectrophotometer. Radioactivity (c.p.m.) was plotted against the amount of templates and the linear regression of each curve was calculated. The absolute number of total mRNA for PRLR was estimated by extrapolating the value of $1 \mathrm{ng}$ total RNA to the internal control. As negative controls, we performed RT-PCR without reverse transcriptase or RNA. The count rates of these negative controls were at the level of background. The coefficient of variation between assays was estimated to be $7 \cdot 4 \%$ for the short form and $5 \cdot 8 \%$ for the long form $(n=8)$.

\section{RIA of $17 \beta$-estradiol and testosterone}

$17 \beta$-Estradiol and testosterone concentrations in plasma were determined using RIA kits (Diagnostic Products Co., Los Angeles, CA, USA). These procedures were based on antibody-coated tubes. Binding of ${ }^{125}$ I-labeled gonadal steroid hormones to their antibodies was competed by gonadal steroid hormones in the sample. After incubation, separation of bound and free ${ }^{125}$ I-labeled hormones was achieved by decanting. Then, the radioactivity in the tubes was counted in a gamma counter, and the quantities of gonadal steroid hormones in the sample were determined according to calibration curves.

The detection limit of the assay for $17 \beta$-estradiol was $0.029 \mathrm{nmol} / \mathrm{l}$, and crossreactivity to other steroid hormones was less than $5 \%$. On the other hand, the detection limit of the assay for testosterone was $0.14 \mathrm{nmol} / 1$ and crossreactivity with dihydrotestosterone was less than $5 \%$.

\section{Statistical analysis}

All results are expressed as the mean \pm s.E.M. Data were analyzed by a non-parametric test (Mann-Whitney U test) and $P$ values $<0.05$ were considered to be statistically significant.

\section{Results}

Comparison of PRLR $m R N A$ in the liver of normal and diabetic mice

Initially we determined by RT-PCR that mRNAs for the long and three short forms of PRLR were present in the liver of both normal and diabetic mice used in this study.
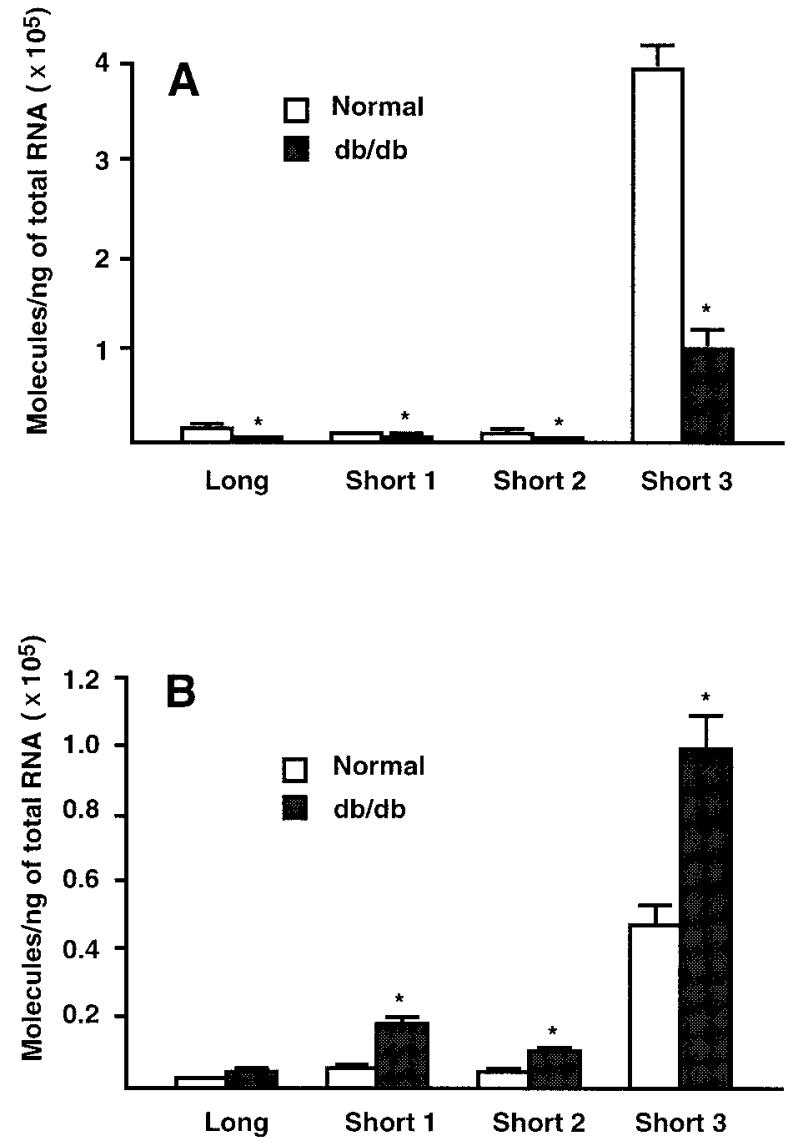

Figure 2 Comparison of mRNAs for long and three short forms of PRLR in normal and diabetic $(\mathrm{db} / \mathrm{db})$ mice at 7 weeks of age. A, female; B, male. The level of each mRNA was determined by RT-PCR and expressed as molecules/ng total RNA as described in Materials and Methods. Each value represents the mean \pm S.E.M. for three separate experiments. ${ }^{*} P<0 \cdot 05$ vs normal mice.

Fig. 2A shows the hepatic levels of mRNA for the four forms of PRLR in both normal and diabetic females of 7 weeks of age. It can be seen that mRNA for PRLR3 was present at a level of $3 \cdot 8 \times 10^{5}$ molecules $/ \mathrm{ng}$ total RNA in normal females and $1.0 \times 10^{5}$ molecules $/ \mathrm{ng}$ total RNA in diabetic females, indicating that the level of PRLR3 mRNA in diabetic females was significantly $(P<0.05)$ lower than in normal females. The short 3 form was most abundant among the four PRLR mRNAs in both cases, and the levels of mRNA for the other three forms of PRLR were also significantly $(P<0.05)$ lower in diabetic mice than in normal mice, although their levels were much lower compared with those of PRLR 3 mRNA.

As shown in Fig. 2B, PRLR3 mRNA was also the most dominant species among the four PRLR mRNAs in both normal and diabetic males of comparable age. In contrast to females, however, the level of PRLR 3 mRNA in diabetic males was $1 \cdot 0 \times 10^{5}$ molecules/ng total RNA, 
which was approximately two times higher than in normal males. The data also indicated that the levels of mRNA for the other two short forms of PRLR were significantly $(P<0 \cdot 05)$ elevated when compared with normal males.

In addition, comparison of the data in Fig. $2 \mathrm{~A}$ and $\mathrm{B}$ revealed that the level of PRLR 3 mRNA in normal females was much higher than in normal males. However, such a sexual difference was not apparent in diabetic mice, partially due to the elevated level of PRLR 3 mRNA in diabetic males. Similar sexual differences were found in the levels of mRNA for long, short 1 and short 2 form PRLR in both normal and diabetic mice, although the levels were much lower than those of PRLR3 mRNA. Accordingly, we focused our studies on PRLR 3 mRNA in subsequent experiments.

Developmental changes in the hepatic level of short form PRLR $m R N A$ in normal and diabetic mice

In order to further investigate the above findings that hepatic levels of PRLR 3 mRNA are different between normal and diabetic mice as well as between sexes, the PRLR 3 mRNA levels in the livers of female and male mice were examined at different stages of postnatal development.

As shown in Fig. 3A, the level of PRLR3 mRNA in normal females increased progressively between 5 and 11 weeks of age. The PRLR3 mRNA level in diabetic females was slightly lower than in normal females at 5 weeks, decreased further to a nadir at 7 weeks and thereafter gradually increased to a level which was about half of that in normal females at 14 weeks.

In male mice, the levels of PRLR 3 mRNA in normal males were lower than those in diabetic mice during 5 to 14 weeks of age, and the mRNA levels decreased gradually during these periods in both cases (Fig. 3B).

Plasma levels of $17 \beta$-estradiol and testosterone in normal and $d b / d b$ mice of different ages

The observed sexual and developmental differences in the hepatic levels of PRLR 3 mRNA suggested the possible involvement of gonadal steroid hormones, $17 \beta$-estradiol and testosterone, which act as a positive and a negative factor respectively, in regulation of PRLR gene expression in the liver (Jahn et al. 1991). Accordingly, plasma levels of $17 \beta$-estradiol and testosterone were examined at various developmental stages of both normal and diabetic mice.

As shown in Table 1, plasma levels of $17 \beta$-estradiol in both normal and diabetic females at 7 weeks of age were below the level of detection $(0 \cdot 029 \mathrm{nmol} / \mathrm{l})$. At 11 and 14 weeks of age, however, normal females had much higher levels compared with diabetic females. On the other hand, the plasma levels of testosterone were lower in normal females than in diabetic females at 7 and 11 weeks of age.
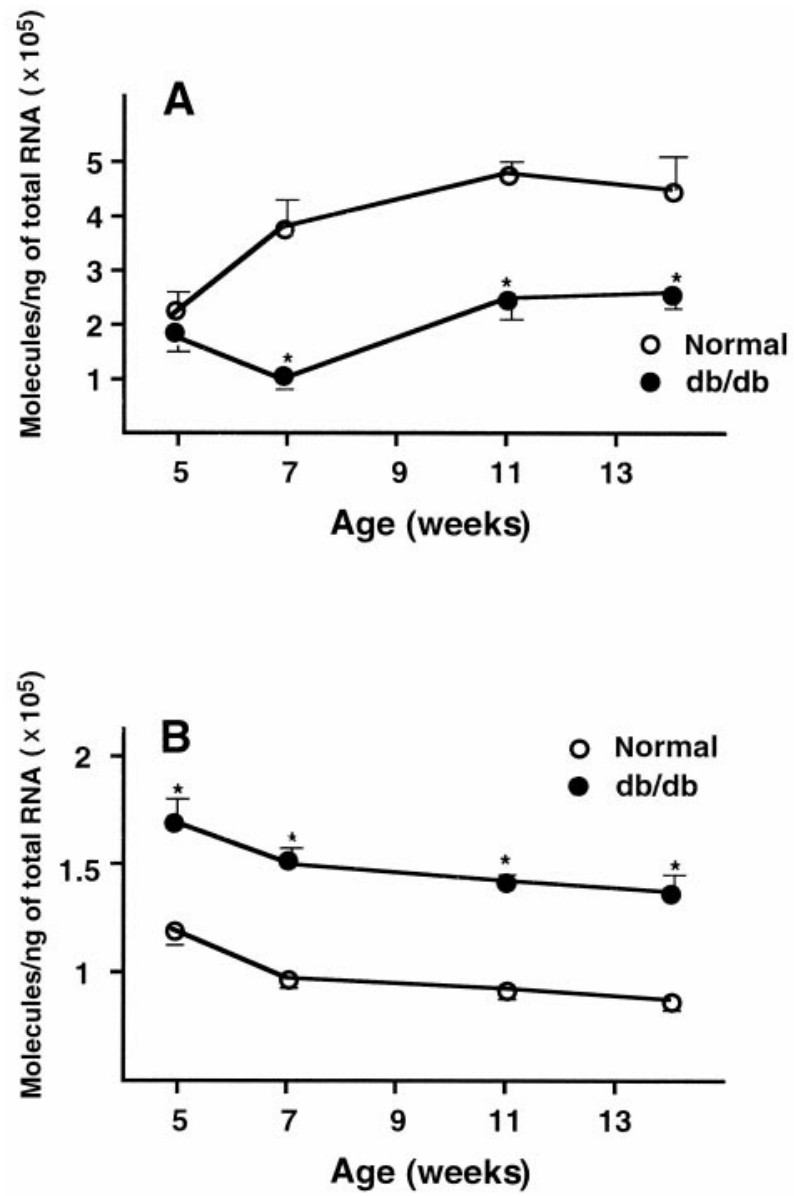

Figure 3 Developmental changes in the level of mRNA for short 3 forms of PRLR in normal and diabetic $(\mathrm{db} / \mathrm{db})$ mice. The levels were determined at the indicated ages. Each value represents the mean \pm S.E.M. of three mice. ${ }^{*} P<0 \cdot 05$ vs normal mice.

In contrast to female mice, plasma levels of $17 \beta-$ estradiol were generally too low to be detected in both normal and diabetic males (Table 2), although some diabetic males had slightly detectable but low levels. Plasma levels of testosterone were clearly higher in normal males than in diabetic males at 7 and 11 weeks of age, although no significant difference was found between the two at 14 weeks. These results indicate that the circulating levels of $17 \beta$-estradiol and testosterone are altered in diabetic female and male mice.

Effects of estradiol and testosterone on the short 3 form of PRLR mRNA in normal mice and $d b / d b$ mice

In order to determine the hepatic response to gonadal steroid hormones, the effects of an 8 day administration of $17 \beta$-estradiol and testosterone on the level of PRLR 3 mRNA in the liver of normal and diabetic mice of 7 weeks of age were examined. The mean plasma levels 
Table 1 Plasma levels $(\mathrm{nmol} / \mathrm{l})$ of $17 \beta$-estradiol and testosterone in normal and $\mathrm{db} / \mathrm{db}$ female mice at different ages. Values are means \pm S.E.M. of three to five mice

\begin{tabular}{|c|c|c|c|}
\hline & \multicolumn{3}{|l|}{ Age (weeks) } \\
\hline & 7 & 11 & 14 \\
\hline \multicolumn{4}{|l|}{$17 \beta$-Estradiol } \\
\hline Normal & $<0.029$ & $0.038 \pm 0.008$ & $0.046 \pm 0.005$ \\
\hline $\mathrm{db} / \mathrm{db}$ & $<0.029$ & $<0.029$ & $0.036 \pm 0.009$ \\
\hline \multicolumn{4}{|l|}{ Testosterone } \\
\hline Normal & $0.31 \pm 0.04^{*}$ & $0.56 \pm 0.03^{*}$ & $0.53 \pm 0.07$ \\
\hline $\mathrm{db} / \mathrm{db}$ & $0.66 \pm 0.16$ & $0 \cdot 86 \pm 0 \cdot 06$ & $0 \cdot 36 \pm 0.02$ \\
\hline
\end{tabular}

${ }^{*} P<0 \cdot 05$ vs $\mathrm{db} / \mathrm{db}$ mice.

Table 2 Plasma levels (nmol/l) of $17 \beta$-estradiol and testosterone in normal and $\mathrm{db} / \mathrm{db}$ male mice at different ages. Values are means \pm S.E.M. of three to five mice

\begin{tabular}{|c|c|c|c|}
\hline & Age (weeks) & & \\
\hline & 7 & 11 & 14 \\
\hline $17 \beta$-Estr & & & \\
\hline Normal & $<0.029$ & $<0.029$ & $<0 \cdot 029$ \\
\hline $\mathrm{db} / \mathrm{db}$ & $<0.029$ & $<0 \cdot 029$ & $<0.029$ \\
\hline Testoste & & & \\
\hline Normal & $10 \cdot 2 \pm 4 \cdot 44^{*}$ & $1 \cdot 23 \pm 0.03 *$ & $0 \cdot 65 \pm 0 \cdot 11$ \\
\hline $\mathrm{db} / \mathrm{db}$ & $0 \cdot 53 \pm 0.19$ & $0.55 \pm 0.03$ & $0 \cdot 88 \pm 0 \cdot 11$ \\
\hline
\end{tabular}

${ }^{*} P<0.05$ vs $\mathrm{db} / \mathrm{db}$ mice.

of $17 \beta$-estradiol in mice treated with $17 \beta$-estradiol were 1.1 and $3.6 \mathrm{nmol} / 1$ in normal and diabetic females and 1.3 and $2.9 \mathrm{nmol} / \mathrm{l}$ in both males respectively. On the other hand, the mean plasma levels of testosterone in mice treated with testosterone propionate were $9 \cdot 3$ and $35.8 \mathrm{nmol} / 1$ in both normal and diabetic females and $29 \cdot 1$ and $29 \cdot 3 \mathrm{nmol} / 1$ in both normal and diabetic males respectively. As shown in Fig. 4A, administration of $17 \beta$-estradiol increased the PRLR3 mRNA level in both normal and diabetic females, although the increase was smaller in diabetic mice. On the other hand, administration of testosterone propionate resulted in substantial decreases in the mRNA levels in both normal and diabetic female mice. Experiments using male mice also indicated that the PRLR 3 mRNA level was slightly increased by $17 \beta$-estradiol treatment and decreased by testosterone treatment in both normal and diabetic mice (Fig. 4B).

\section{Discussion}

In the present study, we examined the hepatic expression of PRLR gene in diabetes mellitus by comparing the levels of mRNA for various forms of PRLR in normal and diabetic $(\mathrm{db}+/ \mathrm{db}+)$ mice of both sexes. In agreement with the previous study (Davis \& Linzer 1989), we found that PRLR 3 mRNA was the most abundant species of PRLR
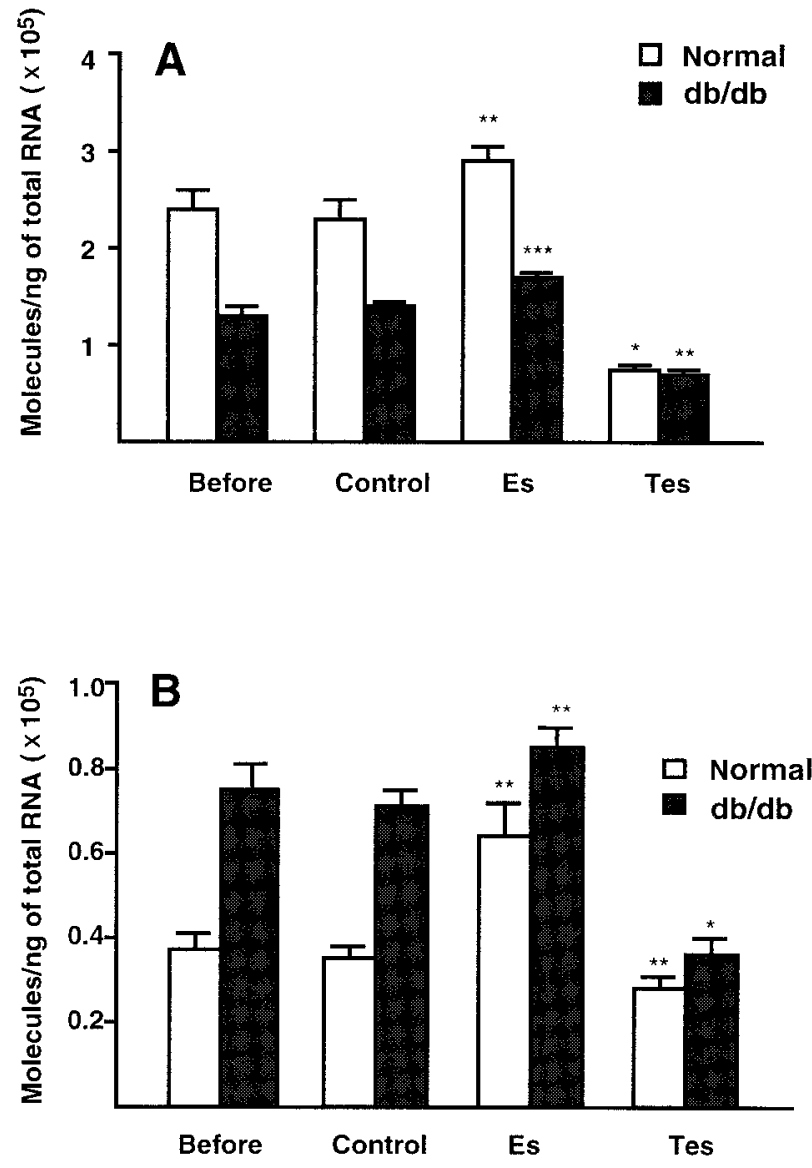

Figure 4 Effects of $17 \beta$-estradiol and testosterone propionate on the level of mRNA for short 3 form of PRLR in (A) female and (B) male mice at 7 weeks of age. $17 \beta$-Estradiol and testosterone were administered for 8 days. Each bar represents the mean \pm S.E.M. $(n=5) .{ }^{*} P<0 \cdot 01,{ }^{*} P<00 \cdot 05,{ }^{*} * P<0 \cdot 1$ vs control. Before, before treatment; Control, oil treated; Es, $17 \beta$-estradiol treated; Tes, testosterone treated.

mRNA in the liver and that its level in normal mice was much higher in females than in males. We also found that the hepatic expression of PRLR gene was clearly altered in diabetic mice of both sexes. Thus, the hepatic level of PRLR3 mRNA in diabetic males was higher than in normal males, whereas the level in diabetic females was lower than in normal females. These results also indicate that gender is a major determinant for the hepatic expression of PRLR gene in both normal and diabetic mice.

Earlier studies showed that the binding activity of PRLR in the liver is regulated positively by estrogen and negatively by androgen (Kelly et al. 1975, 1977). For example, the level of PRL binding sites in female rat liver was shown to decrease after ovariectomy (Kelly et al. 1975), whereas castration caused an increase in the number of PRL binding sites in male liver (Aragona et al. 
1976). In addition, during puberty, when the production and secretion of gonadal steroid hormones increase, the hepatic level of PRL binding sites was found to increase in female but decrease in male rats (Maes et al. 1983). It was also shown immunocytochemically that the amount of PRLR in the liver of gonadectomized rats was increased by estrogen treatment and decreased by androgen treatment (Smirnova et al. 1994). Furthermore, it was recently shown that the levels of mRNA for the long and short forms of PRLR in rat liver decreased in males but increased in females during the course of sexual maturation (Sakaguchi et al. 1994). Our present results show similar developmental changes in the level of PRLR mRNA in the liver of normal male and female mice. Moreover, we found that administration of $17 \beta$-estradiol increased the hepatic level of PRLR3 mRNA in both female and male normal mice, whereas the levels of mRNA in these animals were decreased by testosterone treatment. These data are consistent with the view that both estrogen and testosterone play a major role in regulation of the PRLR gene expression in the liver.

To evaluate the possible involvement of gonadal steroid hormones in altered expression of the PRLR gene in the liver of diabetic mice, we examined the circulating level of $17 \beta$-estradiol and testosterone in diabetic mice. Our studies showed that the plasma levels of testosterone in diabetic female mice were higher than those in normal females, whereas the levels were lower in diabetic male mice than in normal males. On the other hand, the plasma levels of $17 \beta$-estradiol in diabetic female mice were lower than in normal females, whereas the levels were higher in diabetic males than in normal males (Tables 1 and 2). At 14 weeks of age, the levels of PRLR mRNA were significantly reduced in diabetic females, whereas the serum levels of testosterone in normals was higher than in diabetics, and the levels of PRLR mRNA in normal males were significantly reduced whereas the serum levels of testosterone and $17 \beta$-estradiol were similar in normal and diabetic animals. To account for these findings, the involvement of other factors, such as growth hormone and PRL may need to be considered at this stage. Studies with STZ-induced diabetic rats also showed that the circulating level of testosterone decreased in males but increased in females (Baxter et al. 1981). These changes in the circulating levels of gonadal steroid hormones were found to be inversely related to the level of PRLR 3 mRNA in the livers of diabetic males and females, suggesting that alterations in the circulating levels of estrogen and testosterone are, at least in part, responsible for the changes in the hepatic expression of PRLR gene in diabetic mice.

Of the two major gonadal steroid hormones, the inhibitory effect of testosterone was more clearly observed than the stimulatory effect of $17 \beta$-estradiol (Fig. 4). It is conceivable that an increase in plasma testosterone during puberty could decrease the level of PRLR mRNA in diabetic female mice, whereas the decrease in the level of testosterone could account for the rise of PRLR in diabetic male mice. The effect of testosterone appears to be directly on the liver because the liver contains testosterone receptors and testosterone reduces the number of PRL binding sites independently of their effect on plasma PRL (Kelly et al. 1977). In contrast, an increase in the level of plasma $17 \beta$-estradiol could cause the rise of PRLR mRNA in diabetic male mice, whereas a decrease in the level of estradiol in diabetic female mice could reduce the hepatic PRLR mRNA content. The stimulatory effect of estrogen on hepatic PRLR may be mediated, at least in part, by the hypothalamus-hypophyseal system, since estrogen is incapable of increasing the level of PRLR in hypophysectomized rats (Norstedt \& Mode 1982) and pituitary PRL is able to up-regulate its own receptor (Manni et al. 1978). In female diabetic mice, the levels of PRL in orbitally collected sera were lower than normal until 12 weeks of age, and thereafter the levels increased to normal levels (Sinha et al. 1979). These results are consistent with our findings of the changes of hepatic PRLR mRNA in diabetic female mice during the postnatal period. It is possible that the PRLR gene expression is regulated by the balance between the inhibitory effect of testosterone and the stimulatory effect of $17 \beta$-estradiol at different postnatal stages.

We found that both male and female diabetic mice responded to the stimulatory action of estrogen and the inhibitory action of androgen by altering the expression of the PRLR gene when these gonadal steroid hormones were administered. These results suggest that these mice retain their responsiveness to gonadal steroid hormones. It was noted, however, that the response of diabetic mice to estrogen was less than that of normal mice, suggesting that diabetic animals may have some defects in the estrogenreceptor mediated signal transduction pathway. At present, the consequences of altered hepatic expression of PRLR gene in diabetes are unclear, because the functions of PRL and its receptor in the liver are not known. It was reported that PRL stimulates ornithine decarboxylase (Richard 1975), somatomedin release (Francis \& Hill 1975) and the production of synlactin in the liver (Mick \& Nicoll 1985) and regulates the function of bile salt transporter (Ganguly 1997). In STZ-induced diabetic female rats, there is a significant correlation between the reduction in the number of PRL binding sites and the decrease in serum levels of somatomedin-C/insulin-like growth factor-I, suggesting that PRLR may be involved in somatomedin release from the liver (Bryson \& Baxter 1986). Recent studies suggest that the short form of PRLR is internalized and mediates the action of PRL on the liver (Ouhtit $e t$ al. 1994). The physiological roles of the different PRLRs in short isoforms need to be elucidated.

Testosterone has been found to reduce glucose tolerance (Shoupe \& Lobo 1984), whereas estrogen has been shown to increase insulin production (Costrini \& Kalkhoff 1971) and to act with insulin to increase glucose uptake

Journal of Endocrinology (1999) 161, 33-40 
into cells (Kalkhoff 1975). In the diabetic state, testosterone augments susceptibility to development of hyperglycemia, whereas estrogen blocks it (Paik et al. 1982). These observations suggest that the balance of androgenic and estrogenic actions in the liver may be important in the regulation of glucose metabolism. It remains to be determined whether altered expression of the PRLR gene due to gonadal steroid hormones disorders in diabetic mice affects glucose metabolism in the liver. The role of PRL and its receptor in the liver needs to be clarified along with elucidation of the molecular mechanism of PRLR gene expression by gonadal steroid hormones.

\section{References}

Aragona C, Bohnet HG \& Friesen HG 1976 Prolactin binding sites in the male rat liver following castration. Endocrinology 99 1017-1022.

Baxter RC, Bryson JM \& Turtle JR 1981 Changes in rat liver prolactin binding sites in diabetes are sex dependent. Metabolism 30 211-216.

Boutin JM, Jolicoeur C, Okamura H, Gagnon J, Edery M, DusanterFourt I, Djiane J \& Kelly PA 1988 Cloning and expression of the rat prolactin receptor, a member of the growth hormone/prolactin receptor gene family. Cell $\mathbf{5 3}$ 69-77.

Boutin JM, Edery M, Shirota M, Jolicoeur C, Lesueur L, Ali S, Gould D, Djiane J \& Kelly PA 1989 Identification of a cDNA encoding a long form of prolactin receptor in human hepatoma and breast cancer cells. Molecular Endocrinology 3 1455-1461.

Bryson JM \& Baxter RC 1986 Adrenal involvement in the diabetesinduced loss of growth hormone and prolactin receptors in the liver of female rats. Diabetologia 29 106-111.

Buck K, Vanek M, Groner B \& Ball RK 1992 Multiple forms of prolactin receptor messenger ribonucleic acid are specifically expressed and regulated in murine tissues and the mammary cell line HC11. Endocrinology 130 1108-1114.

Costrini NV \& Kalkhoff RK 1971 Relative effects of pregnancy, estradiol and progesterone on plasma insulin and pancreatic islet insulin secretion. Journal of Clinical Investigation 50 992-999.

Davis JA \& Linzer DIH 1989 Expression of multiple forms of the prolactin receptor in mouse liver. Molecular Endocrinology 3 674-680.

Djursing H, Nyholm HC, Hagen C, Carstensen L \& Pedersen LM 1982 Clinical and hormonal characteristics in women with anovulation and insulin-treated diabetes mellitus. American Journal of Obstetrics and Gynecology 143 876-882.

Francis MJO \& Hill DJ 1975 Prolactin stimulated production of somatomedin by rat liver. Nature 255 167-168.

Ganguly TC, O'Brien ML, Karpen SJ, Hyde JF, Suchy FJ \& Vore M 1997 Regulation of the rat liver sodium-dependent bile acid cotransporter gene by prolactin. Journal of Clinical Investigation 99 2906-2914.

Jahn GA, Edery M, Belair L, Kelly PA \& Djiane J 1991 Prolactin receptor gene expression in rat mammary gland and liver during pregnancy and lactation. Endocrinology 128 2976-2984.

Jolicoeur C, Boutin JM, Okamura H, Raguet S, Djiane J \& Kelly PA 1989 Multiple regulation of prolactin receptor gene expression in rat liver. Molecular Endocrinology 3 895-900.

Kalkhoff RK 1975 Effects of oral contraceptive agents on carbohydrate metabolism. Journal of Steroid Biochemistry 6 949-956.

Kelly PA, Posner BI \& Friesen HG 1975 Effects of hypophysectomy, ovariectomy, and cycloheximide on specific binding sites for lactogenic hormones in rat liver. Endocrinology 97 1408-1415.

Kelly PA, Leblanc G, Ferland L, Labrie F \& Lean AD 1977 Androgen inhibition of basal and estrogen-stimulated prolactin binding in rat liver. Molecular and Cellular Endocrinology 9 195-204.
Maes M, Hertogh RD, Watrin-Granger P \& Ketelslegers JM 1983 Ontogeny of liver somatotropic and lactogenic binding sites in male and female rats. Endocrinology 113 1325-1332.

Manni A, Chambers H \& Pearson O 1978 Prolactin induces its own receptor in rat liver. Endocrinology 103 2168-2171.

Mick CCW \& Nicoll CS 1985 Prolactin directly stimulates the liver in vivo to secrete a factor (synlactin) which acts synergistically with the hormone. Endocrinology 116 2049-2056.

Moore RC \& Oka T 1993 Cloning and sequencing of the cDNA encoding the murine mammary gland long-form prolactin receptor. Gene 134 263-265.

Nagano M \& Kelly PA 1994 Tissue distribution and regulation of rat prolactin receptor gene expression - quantitative analysis by polymerase chain reaction. Journal of Biological Chemistry 269 13337-13345.

Norstedt G \& Mode A 1982 On the primary site of action of estrogens and androgens in the regulation of hepatic prolactin receptors. Endocrinology 111 645-649.

Norstedt G, Mode A, Eneroth P \& Gustafsson J-A 1981 Induction of PRL receptors following administration of growth hormone. Endocrinology 108 1855-1861.

Ouhtit A, Ronsin B, Kelly PA \& Morel G 1994 Ultrastructural expression of prolactin receptor in rat liver. Biology of the Cell $\mathbf{8 2}$ 169-176.

Paik S-G, Michelis MA, Kim YT \& Shin S 1982 Induction of insulin-dependent diabetes by streptozotocin - inhibition by estrogens and potentiation by androgens. Diabetes 31 724-729.

Posner BI, Kelly PA \& Friesen HG 1974 Induction of a lactogenic receptor in rat liver: influence of estrogen and the pituitary. Proceedings of the National Academy of Sciences of the USA 71 2407-2410.

Richard JF 1975 Ornithine decarboxylase activity in tissues of prolactin treated rats. Biochemical and Biophysical Research Communications 63 292-299.

Rui H, Djeu JY, Evans GA, Kelly PA \& Farrar WL 1992 Prolactin receptor triggering. Journal of Biological Chemistry 267 24076-24081.

Sakaguchi K, Ohkubo T, Sugiyama T, Tanaka M, Ushiro H \& Nakashima K 1994 Differential regulation of prolactin receptor mRNA expression in rat liver and kidney by testosterone and oestradiol. Journal of Endocrinology 143 383-392.

Sambrook J, Maniatis T \& Fritsch EF 1989 Molecular Cloning - A Laboratory Manual, edn 2, pp 7.19-7.22. Cold Spring Harbor: Cold Spring Harbor Laboratory Press.

Semple CG, Gray CE \& Beastall GH 1988 Androgen levels in men with diabetes mellitus. Diabetic Medicine 5 122-125.

Shirota M, Banville D, Ali S, Jolicoeur C, Boutin JM, Edery M, Djiane J \& Kelly PA 1990 Expression of two forms of prolactin receptor in rat ovary and liver. Molecular Endocrinology 4 1136-1143.

Shoupe D \& Lobo R 1984 The influence of androgens on insulin resistance. Fertility and Sterility 41 385-388.

Sinha YN, Baxter SR, Larson BA \& Vanderlaan WP 1979 Levels of prolactin, growth hormone and insulin in genetically diabetic $(\mathrm{db} / \mathrm{db})$ mice. Proceedings of the Society for Experimental Biology and Medicine 161 78-81.

Smirnova OV, Petraschuk OM \& Kelly PA 1994 Immunocytochemical localization of prolactin receptors in rat liver cells. I Dependence on sex and sex steroids. Molecular and Cellular Endocrinology 105 77-81.

Wang AM, Doyle MV \& Mark DF 1989 Quantitation of mRNA by the polymerase chain reaction. Proceedings of the National Academy of Sciences of the USA 86 9717-9721.

Received 2 April 1998

Revised manuscript received 10 September 1998 Accepted 9 November 1998 